\title{
Gender Based Comparative Analysis of Workers Participation in Agriculture in Rural Areas of Uttarakhand: A Study of Sahaspur Development Block
}

\author{
Prashant Kandari ${ }^{{ }^{*}}$, Uma Bahuguna ${ }^{2}$ and Rukmani ${ }^{1}$ \\ ${ }^{1}$ Department of Economics, Campus Pauri, H.N.B. Garhwal Central University, Uttarakhand, India \\ ${ }^{2}$ Department of Sociology, Campus Srinagar, H.N.B. Garhwal Central University, Uttarakhand, India \\ *Corresponding author: kandari1980@gmail.com
}

\begin{abstract}
Amidst the huge migration of the males tough working and living working conditions, the females of the Hill Rural regions of Uttarakhand largely share the burden of the economy of these regions. Many studies depict that female participation is decreasing in the rural areas. Amidst the low declining work force participation of women in India, a few changing patterns can be observed. The first is a shift away from agriculture over the last decade 1999-2000 to 2011-12, and the second is the gain in education of regular employment even during the period 2004-2012, when the overall work force participation rates are declining. The study of the workers participation in Uttarakhand state as per 2011 census shows that female work participation rate is 26.7 percent, which has decreased from the year 2001 when it was 27.3 percent and the same is noticed in the rural areas of the state. The present study conducted in the rural region of Uttarakhand do not totally corroborate these facts and indicates that female work participation in agriculture which is largely carried out for meeting the subsistence level of household demand is still higher under various conditions. The comparison of male-female participation in pre and Post harvest agricultural activities reflect the fact that even after higher rate of participation of females in agriculture, males have larger role in key agriculture activities that require decision making (Ploughing, selection of seeds, and spraying of chemical fertilizers-Pre-harvest; Marketing- post harvest). The overall analysis of the male-female participation in pre and post harvest activities clearly shows that females have higher participation rate in agriculture than males. The study further highlights the factors which lead towards higher preference for female agriculture labour and hence deals with their higher participation rate in agriculture activities in these regions.
\end{abstract}

Keywords: Hill Rural Areas, Female Participation, Pre and post harvest, Agriculture

The tough natural and geographical settings of rural regions of Uttarakhand have indirectly enacted in way of the growth of employment opportunities in these regions as they are not conducive for industrial development. This has always led to the problem of lack of employment opportunities in these regions, which is further accentuated by the poor infrastructural development of these regions. Agriculture and the allied activities are the only source of living to small extent and a source of subsistence to a large extent for the residents of these backward areas. The poor development of agriculture categorised by small land holdings, poor irrigation facilities, terraced type farming pattern and many other problems have pushed back agriculture thus failing it to even act as a source of mere subsistence rather than acting as a major income generator for the residents of these areas. The large scale out-migration of men in search of employment in the plains or in the army has led to a demographic imbalance in the region. While men predominate in urban areas, the interior rural districts are amongst the few in all of India that contain significant woman majorities (Rawat, 2004). 
When men migrate to cities, apart from the domestic chores of cooking, fetching fuel, fodder and water, looking after children, the tasks of caring for livestock and agricultural work also fall on women's shoulders. (Sekhar, 2007) found that women's participation in the rural economy is significant. In Uttarakhand, young men generally migrate to the plains in search of employment, whereas women are left behind to cultivate the land and take care of the children and the older generation. Since agricultural fields are located on terraces in the hilly region and are generally very small, modern agricultural implements cannot be used. As a result, agricultural work becomes highly time-consuming, thus increasing women's workload tremendously. Men prefer to do less time-consuming work which requires less labour, and generates more and quick money. They do not show much interest in routine agricultural work because it requires hard labour and is less productive. Therefore, instead of sharing the work with women, they prefer to migrate to urban areas (Nautiyal, 2003). Majority of villages lack the basic infrastructure, while the prevalence of differentiation on the basis of caste, creed and gender is still dominant, further social malice's like dowry system, violence on women, alcoholism are prevalent. Women are the major sufferers of this malevolence prevalent in the rural areas of the district. Poverty and unemployment are the other problems which aggravates the tribulations of the women in these areas.

Women of these areas, though they carry the burden of all these problems they play a vital role in the economy of these regions. The participation of women in agriculture and allied activities is significantly large when compared to males; further the increasing migration of males to the urban areas, mainly the youths has overburdened the women of these areas. This segment of population survives in most difficult working and living conditions.
Agriculture among such tough circumstances occupy a major source of subsistence among the residents of these areas but due to the problems of migration, reduced participation of males, changing agricultural techniques and others, it is under the severe threat of failing even as a source of living.

Work participation rate (WPR) is an important indicator of development showing the proportion of working population to the total population in an economy. It is generally believed that higher WPR is an indication of well-being of population and rightly so. Conversely, it is also observed that in a poor region, WPR is generally higher among the population which does not necessarily indicate improved economic status and well-being, rather it indicates a poverty driven phenomenon. In poor regions, people do not have perennial source of employment and they are engaged in multiple activities for short duration at low wage rates. Such multi-activity is often most common in such regions to cope with the livelihood uncertainty.

As per MOSPI, GOI, Female work participation rate in Uttarakhand have consistently declined during 2004-05 to 2011-12. The distinctive feature of participation rate is a huge decline of female participation rate in period 2001 to 2011 when compared to the earlier periods. This drop in female participation rate has been regarded as a welcome indicator as there has been a considerable increase of people, particularly of younger age groups, in educational institutions that caused reduction in Work Force participation rates. Also, high Labour Force Participation rate (LFPR) may be indicative of poverty driven phenomenon particularly in a subsistence economy. Male participation rates have shown a significant increase (6.6 percentage points) during 2011-12 over 2009-10. The similar trend emerges in the rural areas, however in urban areas participation rates tend to increase by and large and more particularly during 2011-12.

Table 1: Work participation rate in Uttarakhand (UPSS)

\begin{tabular}{cccccccccc}
\hline \multirow{2}{*}{$\begin{array}{c}\text { NSS } \\
\text { Round }\end{array}$} & \multicolumn{3}{c}{ Rural } & \multicolumn{3}{c}{ Urban } & \multicolumn{3}{c}{ Total } \\
\cline { 2 - 10 } & Male & Female & Total & Male & Female & Total & Male & Female & Total \\
\hline $2004-05$ & 52.3 & 42.7 & 47.4 & 51.9 & 12.7 & 33.2 & 52.2 & 35.7 & 43.9 \\
$2009-10$ & 46.1 & 39.9 & 43.1 & 53.0 & 11.3 & 33.6 & 47.8 & 33.0 & 40.7 \\
$2011-12$ & 54.3 & 24.8 & 39.9 & 54.6 & 14.7 & 35.5 & 54.4 & 21.9 & 38.6 \\
\hline
\end{tabular}

Source: NSS various rounds 
The noticeable feature of LFPR in the rural areas in the state is a very high LFPR among females compared to all-India. The main reason for such a high LFPR among females is subsistence nature of agriculture economy that provides the only source of employment and there are limited opportunities of employment outside agriculture. The most distinguishable feature of LFPR in the rural areas is, therefore disproportionately a very high female LFPR when compared to the national average. One of the reasons for substantively higher rate of LFPR among females is not a demographic phenomenon, rather it is purely an economic phenomenon where a large percentage of males do out-migrate for earning cash income and females replace their labour, thereby increasing their overall participation rate.

\section{Objectives of the study}

- To examine the association of demographical aspects and work force participation of the workers engaged in agriculture in Sahaspur Block, Dehradun.

- To access and compare the nature of female work participation in pre-harvest and postharvest activities of agriculture with that of males, with special reference to Sahaspur block, Dehradun.

\section{Research methodology}

Dehradun comprises of six developmental blocks, viz., Raipur, Doiwala, Sahaspur, Vikas Nagar, Kalsi and Chakrata. For the present study, Sahaspur Block of District Dehradun has been selected. For the present study, multistage random sampling (by lottery method) has been used. In the first stage, from each Nyay Panchayat, $40 \%$ of the Gram Panchayats have been selected randomly. In the second stage, from the selected Gram Panchayats within each Nyay Panchayat, $40 \%$ of the villages have been selected randomly which leads to a total sample of 20 villages. In the third stage from each of the selected villages, 15 households involved in agriculture have been selected randomly. This gives us a sample size of 300 households. In the final stage, from each of these selected households, one main male and one main female member involved in agriculture have been selected between the ages of 18 and 70 years, who are working on their own land. Hence, for the present work a sample of 291 females and 291 males (291 households) was extracted for the study.

\section{Socio-economic profile of male and female workforce engaged in Pre-harvest activities}

Following data depicts the socio-economic dimensions of male and female workers involved in agriculture activities in the Sahaspur block of Dehradun district.

\section{Socio-economic analysis of work force participation}

Unemployment at the prime working age-group characterizes the vulnerability of households that has widespread ramifications to livelihood options in the limited segment of labour market. Yet another conspicuous feature noted in the NSSO data is that of increasing Work Force participation Rates for males and females in the older age-group (59 years and above), which probably indicates compulsion on the part of old-age population to search for employment under duress conditions. This is opposite to the earlier trend (1994-2000) of withdrawing from the labour market which might be attributed to some extent due to retirement and voluntary withdrawal from the labour market as a result of enhanced earnings of younger population. Increasing pressure in the labour market and elderly joining the employment market is not a healthy trend. Bit contrary to the latest trend revealed by NSSO, the Table 2 shows that male participation among higher age group i.e. 41-60 years is larger than females in the similar age group, while female participation among younger age group i.e. 18-40 years is higher than that of the males in the same age group in these regions.

The higher participation of higher age group males could be attributed to the fact that since the younger males are largely involved in other income earning activities, the older ones are forced to support the females in the work, which is largely heavy and demands male labour involvement. The present study, which shows a significant participation of females belonging to younger age-groups is a cause for concern. Whether school/college going population has actually reverted back to labour market under compulsion conditions seems to be the most worrisome concern. The other factor 
Table 2: Socio-economic Characteristics of Male and Female Workers

\begin{tabular}{cccccc}
\hline \multirow{2}{*}{ Variables } & Categories & \multicolumn{2}{c}{ Females } & \multicolumn{2}{c}{ Males } \\
\cline { 2 - 6 } & $18-30$ & $\begin{array}{c}\text { No. of Female } \\
\text { workers }\end{array}$ & Percentage & $\begin{array}{c}\text { No. of Male } \\
\text { workers }\end{array}$ & Percentage \\
\hline \multirow{5}{*}{ Age (Years) } & $31-40$ & 130 & 15.12 & 19 & 6.53 \\
& $41-50$ & 71 & 44.67 & 54 & 18.56 \\
& $51-60$ & 36 & 12.37 & 100 & 34.36 \\
& $>60$ & 10 & 3.44 & 26 & 31.62 \\
Marital Status & Single & 4 & 1.37 & 16 & 8.93 \\
& Married & 259 & 89 & 269 & 5.5 \\
& Widowed & 28 & 9.62 & 6 & 2.06 \\
& Divorced & 0 & 0 & 0 & 0 \\
& Uneducated & 122 & 41.92 & 49 & 16.84 \\
Education & Primary & 42 & 14.43 & 32 & 11 \\
& Upper Primary & 21 & 7.22 & 20 & 6.87 \\
& Secondary & 23 & 7.9 & 41 & 14.09 \\
& Sr. Secondary & 48 & 16.49 & 62 & 21.31 \\
& Graduate & 31 & 10.65 & 62 & 21.31 \\
& Post-Graduate \& above & 4 & 1.37 & 25 & 8.58 \\
& Agriculture & 284 & 97.59 & 54 & 18.56 \\
& Government Job & 5 & 1.72 & 53 & 18.21 \\
Main Occupation & Private Job & 0 & 0 & 144 & 49.48 \\
& Self Employed & 2 & 0.69 & 33 & 11.34 \\
& Others & 0 & 0 & 7 & 2.41 \\
\hline
\end{tabular}

Source: Primary Survey

which attributes to the young female participation in agriculture is getting married, which somehow reduces their chances of educational attainment in the backdrop of heavy work pressures and traditional cultures still persisting in these under developed economies. Adding to these factors, Olsen and Mehta (2006) found that economic poverty makes female labour force participation more likely.

Women workers in rural India registered a significant decline from 2004-05, whereas reverse trends are traceable in the case of urban India. From 2004-05 to 2009-10, the number of women workers dropped by 21.3 million, of which 19.5 million were in rural areas. (Ruchika Chaudhary and Sher Verick, 2014). The higher female participation of females in agriculture, which is largely carried out for subsistence in these areas is due to the higher level of illiteracy prevalent among them in these regions, which decrease their chances of gaining any other form of non-agriculture employment due to the lack of skills and other social issues as observed in the study. The extent of time contributed to domestic chores also decreases their chances of looking for non-agriculture employment opportunities. The present study shows contrary facts to studies which depict the shift of LFPR from that in agriculture to non-agricultural activities, which could be corroborated by the fact that female participation in non-agriculture activities is highly low relatively to that of males. The present study further shows that even the higher level of per capita consumption level and higher male participation in the nonagriculture income generating activities have not affected the higher levels of female participation rate in agriculture activities in these regions. Bibhu Behera \& Anama Behera (2013) in their research have emphasized on the fact that most of the farming activities $(80 \%)$ are done by females, so they have called this era as Feminization of Agriculture \& Female face of Farming. 


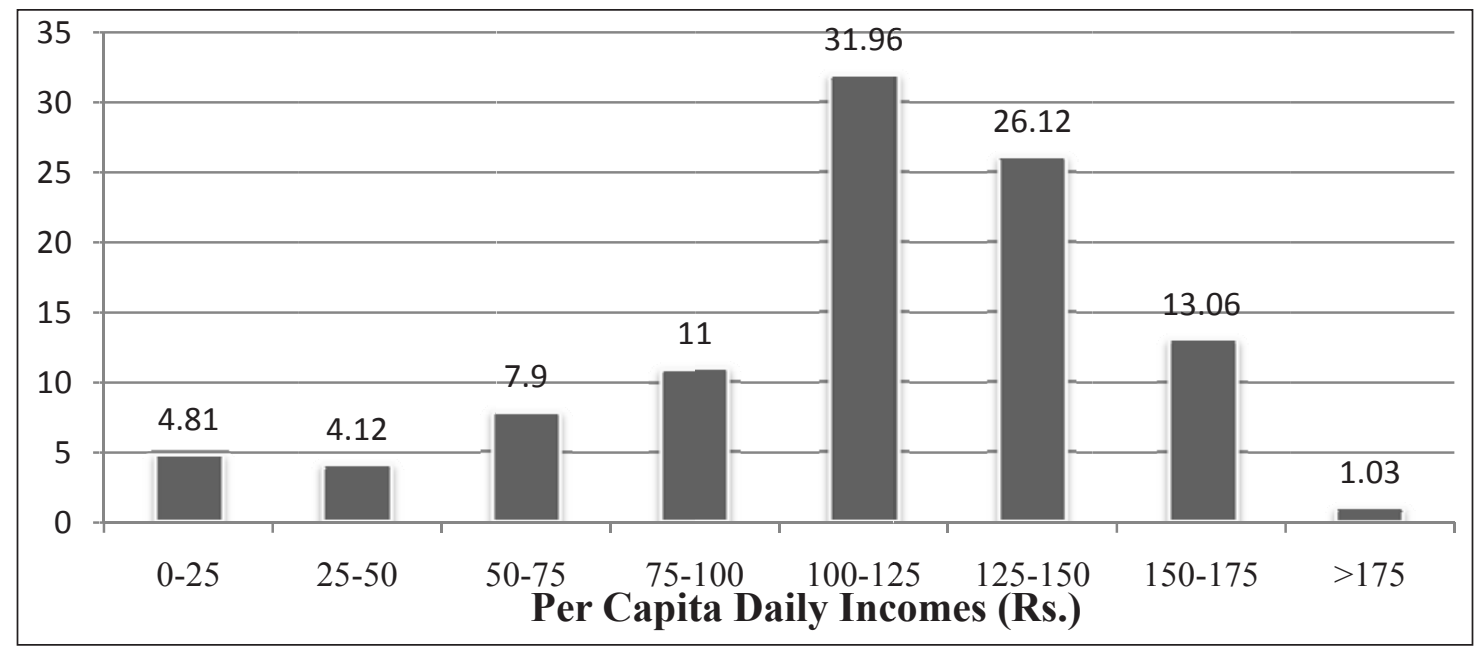

Fig. 1: Distributions of Households on basis of their household Per Capita Daily Incomes (\%)

Source: Primary Survey

Fig. 1 compares the number of households falling under various income brackets, on the basis of the households' per capita daily income. The average per capita daily income in rural India is ₹ 12.91 , while that for Uttarakhand is slightly higher at ₹ 16.44 (India Human Development Survey 2004-05). In comparison, Sahaspur Block is quite prosperous, with 95.19 per cent of the households' per capita daily incomes above ₹ 25 , and it is above ₹ 100 for 72 per cent of the households. This is attributable to several factors. Firstly, Sahaspur Block is situated close to Dehradun city, which is the state capital, hence there is easy access to markets, government subsidiaries, beej bhandars etc. when compared to the rest of Uttarakhand. Secondly, a major proportion of males have part-time or full-time employment in addition to agriculture, which boosts the households' income.

Table 3: Purpose of Production of Food Grains in Sahaspur Block

\begin{tabular}{ccc}
\hline Purpose & $\begin{array}{c}\text { No. of Agricultural } \\
\text { Households }\end{array}$ & Percentage (\%) \\
\hline $\begin{array}{c}\text { For self-consumption } \\
\text { (Subsistence) }\end{array}$ & 179 & 61.5 \\
$\begin{array}{c}\text { For both self- } \\
\text { consumption and } \\
\text { commercial use }\end{array}$ & 97 & 33.3 \\
$\begin{array}{c}\text { For commercial } \\
\text { purpose }\end{array}$ & 15 & 5.2 \\
$\quad$ Total & $\mathbf{2 9 1}$ & $\mathbf{1 0 0}$ \\
\hline
\end{tabular}

Source: Primary Survey.
Table 3 depicts that agriculture activities in the region are largely carried out by the rural households to meet their self-consumption needs. This is attributed to various factors like less farm size, use of poor technology, lack of various required agriculture inputs etc leading to low level of productivity and less developed state of agriculture activities. Only 33 percent of the households utilise the agriculture produce for commercial use apart from meeting their self consumption requirements.

Table 4: Fulfillment of Family Responsibility Along with Agriculture

\begin{tabular}{ccc}
\hline $\begin{array}{c}\text { Fulfillment } \\
\text { of Family } \\
\text { Responsibility }\end{array}$ & $\begin{array}{c}\text { No. of Female } \\
\text { Workers }\end{array}$ & $\begin{array}{c}\text { Percentage } \\
\text { (\%) }\end{array}$ \\
\hline Yes & 291 & 100 \\
No & 0 & 0 \\
Total & 291 & 100 \\
\hline
\end{tabular}

Source: Primary Survey

Fulfillment of family responsibility along with agriculture is presented in Table 4, which depicts that all the female workers involved in agriculture in Sahaspur block carry out their familial and household responsibilities as well. This is praiseworthy and puts extra work burden on females, as managing the family, childcare, cooking, cleaning and other household chores require time, effort and commitment. Yet all female workers of 
Sahaspur block are able to do all this, and also are fulfilling the demands of agriculture.

\section{Comparison of male and female work participation in pre-harvest activities of agriculture}

To facilitate comparison between male and female work participation, both the pre-harvest and postharvest agricultural activities are divided into various sub activities. Each male and female worker marked their levels of participation in each activity on a four-point rating scale ( $1=$ Never, $2=$ Sometimes, $3=$ Mostly, 4=Always), and the summated score of all activities within each work area is calculated for each respondent. The means of the summated score for male and female workers are used to compare their respective levels of participation in that work area. Independent samples two-tailed t-test has been used to check whether the difference in levels of participation of male and female workers is statistically significant or not. In cases where Levene's test is violated, Independent Samples Mann-Whitney U-test is used in addition to t-test to corroborate the results.

Table 5: Rank based distribution of the work participation rate in Pre-harvest activities

\begin{tabular}{ccccc}
\hline $\begin{array}{c}\text { Pre-Harvest } \\
\text { Activities }\end{array}$ & \multicolumn{2}{c}{$\begin{array}{c}\text { Female's } \\
\text { Participation }\end{array}$} & \multicolumn{2}{c}{$\begin{array}{c}\text { Male's } \\
\text { Participation }\end{array}$} \\
\cline { 2 - 5 } & Mean & Rank & Mean & Rank \\
\hline Ploughing & 1.09 & 10 & 3.53 & 1 \\
Selection of seed & 2.27 & 8 & 3.26 & 2 \\
Preparation of seed & 3.75 & 4 & 1.99 & 8 \\
Irrigation & 3.26 & 7 & 2.46 & 6 \\
Sowing & 3.73 & 5 & 2.60 & 5 \\
Transplantation & 3.67 & 6 & 2.19 & 7 \\
Weeding & 3.86 & 2 & 1.60 & 9 \\
Manuring & 3.92 & 1 & 1.57 & 10 \\
Spraying of chemical & 2.10 & 9 & 3.03 & 3 \\
fertilizer & 3.77 & 3 & 2.77 & 4 \\
\hline Harvesting & & & & \\
\hline
\end{tabular}

Source: Primary Survey.

The study shows that in heavy work like ploughing and in work largely associated with primary decision making i.e. seed selection, male participation is higher than that of females in these regions.

\begin{tabular}{cccccc}
\hline \multicolumn{6}{c}{ Group Statistics of Pre-Harvest Activity } \\
\hline & SEX & N & Mean & $\begin{array}{c}\text { Std. } \\
\text { Deviation }\end{array}$ & $\begin{array}{c}\text { Std. Error } \\
\text { Mean }\end{array}$ \\
\hline $\begin{array}{c}\text { Pre_- } \\
\text { harvest }\end{array}$ & Females & 291 & 31.43 & 2.363 & .139 \\
\hline
\end{tabular}

\section{Hypothesis testing:}

- $\mathbf{H}_{0}$ : There is statistically no significant difference in the levels of participation of male and female workers of Sahaspur block in pre-harvest activities.

- $\mathbf{H}_{\mathbf{1}}$ : There is statistically a significant difference in the levels of participation of male and female workers of Sahaspur block in pre-harvest activities.

A t-test succeeded to reveal a statistically reliable difference between the mean participation levels of females $(\mathrm{M}=31.43, \mathrm{SD}=2.363)$ and males $(\mathrm{M}=24.99$, $\mathrm{SD}=3.232), \mathrm{t}(531.150)=27.439, \mathrm{p}=.000, \alpha=.05$.

However, as Levene's test is violated (sig < .05), Independent Samples Mann-Whitney U-test is also used.

\begin{tabular}{|c|c|c|c|}
\hline \multicolumn{4}{|c|}{ Hypothesis Test Summary } \\
\hline Null hypothesis & Test & Sig. & Decision \\
\hline $\begin{array}{l}\text { The distribution } \\
\text { of Pre_HARVEST } \\
\text { is the same across } \\
\text { categories of sex }\end{array}$ & $\begin{array}{l}\text { Independent- } \\
\text { Samples Mann- } \\
\text { Whitney U Test }\end{array}$ & .000 & $\begin{array}{c}\text { Reject } \\
\text { the Null } \\
\text { Hypothesis }\end{array}$ \\
\hline
\end{tabular}

Asymptotic Significances are displayed. The significance level is .05.

\begin{tabular}{ccccc}
\hline \multicolumn{5}{c}{ Mann-Whitney U-test Ranks } \\
\hline & SEX & N & $\begin{array}{c}\text { Mean } \\
\text { Rank }\end{array}$ & $\begin{array}{c}\text { Sum of } \\
\text { Ranks }\end{array}$ \\
\hline \multirow{2}{*}{ PRE__ } & FEMALES & 291 & 421.19 & 122565.50 \\
HARVEST & MALES & 291 & 161.81 & 47087.50 \\
& Total & 582 & & \\
\hline
\end{tabular}

The statistics analysis indicates that as the mean rank for females is much higher than males, it can be concluded that the level of participation of female workers is significantly higher than male workers of Sahaspur block in the pre-harvest activities.

The post-harvest activities which are basically largely decision led are associated with higher male participation. 


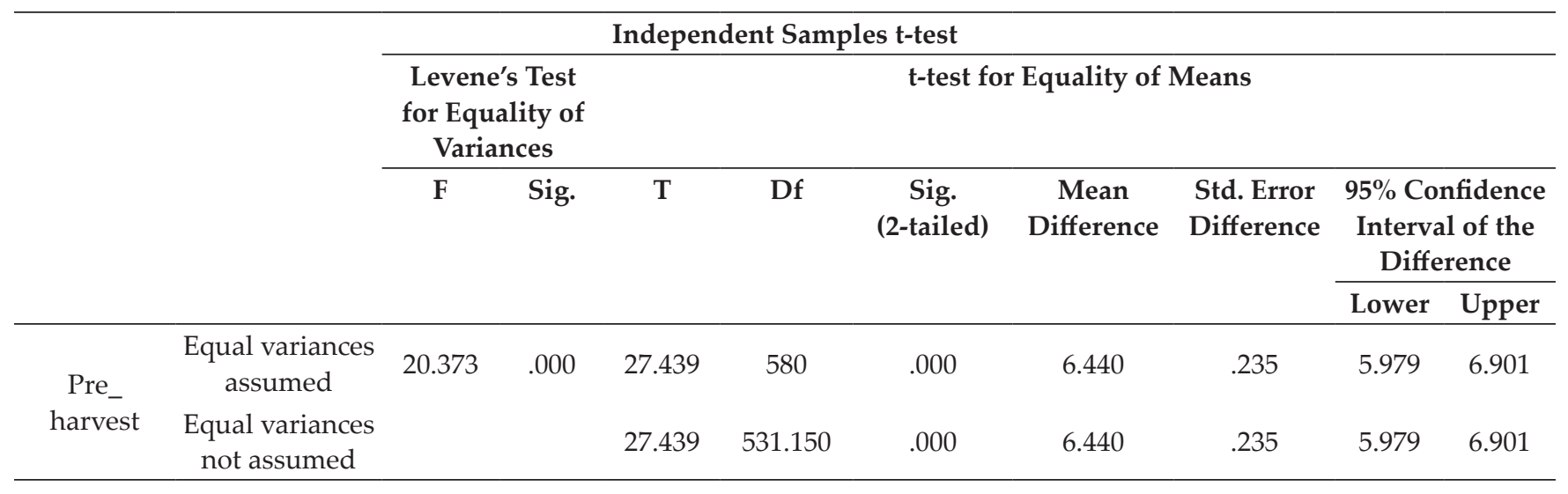

Table 6: Rank based distribution of the work participation rate in Post-harvest activities

\begin{tabular}{ccccc}
\hline \multirow{2}{*}{ Pre-Harvest Activities } & \multicolumn{2}{c}{ Female's Participation } & \multicolumn{2}{c}{ Male's Participation } \\
\cline { 2 - 5 } & Mean & Rank & Mean & Rank \\
\hline Shifting produce to processing facility & 3.47 & 8 & 3.11 & 1 \\
Threshing & 3.53 & 7 & 2.31 & 2 \\
Husking & 3.80 & 5 & 2.09 & 3 \\
Winnowing & 3.85 & 4 & 1.67 & 4 \\
Sieving & 3.75 & 6 & 1.23 & 9 \\
Drying of food grains & 3.90 & 2 & 1.36 & 6 \\
Cleaning of food grains & 3.94 & 1 & 1.28 & 8 \\
Storage of food grains & 3.88 & 3 & 1.25 & 5 \\
Marketing & 1.56 & 9 & 1.58 & \\
\hline
\end{tabular}

Source: Primary Survey

\begin{tabular}{cccccc}
\hline \multicolumn{5}{c}{ Group Statistics of Post-Harvest Activity } \\
\hline & Sex & N & Mean & $\begin{array}{c}\text { Std. } \\
\text { Deviation }\end{array}$ & $\begin{array}{c}\text { Std. Error } \\
\text { Mean }\end{array}$ \\
\hline $\begin{array}{c}\text { Post_} \\
\text { harvest }\end{array}$ & Females & 291 & 31.65 & 1.911 & .112 \\
\hline
\end{tabular}

\section{Hypothesis testing}

- $\mathbf{H}_{0}$ : There is statistically no significant difference in the levels of participation of male and female workers of Sahaspur block in post-harvest activities.

- $\mathbf{H}_{\mathbf{1}}$ : There is statistically a significant difference in the levels of participation of male and female workers of Sahaspur block in post-harvest activities.

A t-test succeeded to reveal a statistically reliable difference between the mean participation levels of females $(\mathrm{M}=31.65, \mathrm{SD}=1.911)$ and males $(\mathrm{M}=16.02$, $\mathrm{SD}=2.921), \mathrm{t}(499.713)=76.346, \mathrm{p}=.000, \alpha=.05$.

\begin{tabular}{|c|c|c|c|c|c|c|c|c|c|c|}
\hline \multicolumn{11}{|c|}{ Independent Samples t-test } \\
\hline & & \multicolumn{2}{|c|}{$\begin{array}{l}\text { Levene's Test } \\
\text { for Equality of } \\
\text { Variances }\end{array}$} & \multicolumn{7}{|c|}{ t-test for Equality of Means } \\
\hline & & \multirow[t]{2}{*}{ F } & \multirow[t]{2}{*}{ Sig. } & \multirow[t]{2}{*}{$\mathrm{T}$} & \multirow[t]{2}{*}{ Df } & \multirow[t]{2}{*}{$\begin{array}{c}\text { Sig. } \\
\text { (2-tailed) }\end{array}$} & \multirow[t]{2}{*}{$\begin{array}{c}\text { Mean } \\
\text { Difference }\end{array}$} & \multirow[t]{2}{*}{$\begin{array}{l}\text { Std. Error } \\
\text { Difference }\end{array}$} & \multicolumn{2}{|c|}{$\begin{array}{l}95 \% \text { Confidence } \\
\text { Interval of the } \\
\text { Difference }\end{array}$} \\
\hline & & & & & & & & & Lower & Upper \\
\hline \multirow{2}{*}{$\begin{array}{l}\text { POST_} \\
\text { HARVEST }\end{array}$} & $\begin{array}{c}\text { Equal variances } \\
\text { assumed }\end{array}$ & 36.019 & .000 & 76.346 & 580 & .000 & 15.622 & .205 & 15.220 & 16.024 \\
\hline & $\begin{array}{c}\text { Equal variances } \\
\text { not assumed }\end{array}$ & & & 76.346 & 499.713 & .000 & 15.622 & .205 & 15.220 & 16.024 \\
\hline
\end{tabular}


However, as Levene's test is violated (sig < .05), Independent Samples Mann-Whitney U-test is also used.

\begin{tabular}{cccc}
\hline \multicolumn{4}{c}{ Hypothesis Test Summary } \\
\hline Null hypothesis & Test & Sig. & Decision \\
\hline The distribution of & Independent- & .000 & Reject \\
POST_HARVEST & Samples & & the Null \\
is the same across & Mann- & Hypothesis \\
categories of sex & Whitney U & \\
& Test & \\
\hline
\end{tabular}

Asymptotic Significances are displayed. The significance level is .05.

The Independent Samples Mann-Whitney U-test suggests the null hypothesis to be rejected, and the alternate hypothesis to be accepted. This supports the result given by the independent samples two tailed t-test.

\begin{tabular}{ccccc}
\hline \multicolumn{5}{c}{ Mann-Whitney U-test Ranks } \\
\hline & Sex & N & $\begin{array}{c}\text { Mean } \\
\text { Rank }\end{array}$ & $\begin{array}{c}\text { Sum of } \\
\text { Ranks }\end{array}$ \\
\hline POST & Females & 291 & 436.95 & 127151.00 \\
HARVEST & Males & 291 & 146.05 & 42502.00 \\
& Total & 582 & & \\
\hline
\end{tabular}

As the mean rank for females is much higher than males, it can be concluded that the level of participation of female workers is significantly higher than male workers of Sahaspur block, in post-harvest activities.

Table 7: Preference for Agricultural Labour (Males/ Females)

\begin{tabular}{ccc}
\hline $\begin{array}{c}\text { Preference for } \\
\text { Agricultural Labour }\end{array}$ & $\begin{array}{c}\text { No. of Agricultural } \\
\text { Households }\end{array}$ & $\begin{array}{c}\text { Percentage } \\
\mathbf{( \% )}\end{array}$ \\
\hline Females & 107 & 71.81 \\
Males & 42 & 28.19 \\
Total & 149 & 100.00 \\
\hline
\end{tabular}

Source: Primary Survey

The above data depicts that 71.81 per cent of the households employing agricultural labour for agricultural activities on their farms prefer female workers to male workers. Females on the other hand can be employed at lower wages than male workers, can work for long working hours without getting paid extra to complete their farm work on time, and are thus preferred for all other activities. Amrit Patel (2012) Women are invariably paid lower wages than men for the same agricultural work. Further, male workers are often unwilling to do several tasks when it comes to doing jobs which are traditionally seen as women's work. Female workers, on the other hand, have no such hassles, and generally will do whatever they are asked to do.

\section{CONCLUSION}

The present study concludes that Women play an important and central role in agricultural development apart from carrying the burden of domestic household activities in these rural regions. "In the present time or so the females have started to play more active role in the economic arena moving out from their domestic boundaries. This is a positive aspect not only for them but also for these regions which are degrading out rapidly due to heavy migration, mainly of the male youths." (Kandari and Bahuguna, 2017). The demographic analysis of women agriculture workers reveals their poor educational status, higher participation rate in younger age group and also exhibits the facts that they are largely involved in agriculture activities after getting married. The lower educational status restricts their participation probabilities in other employment sectors and further the increasing burden after entering in higher age group leads to their non-absorption in agricultural activities. Women although have a larger participation in agriculture activities than males but it is largely restricted to those pre-harvest activities, which generally do not require any decision-making. The larger involvement of males in such agriculture activities which requires decision making is the extension and existence of traditional patriarchal social structure among rural communities, which holds the perception that males are more suited for decision making. They are lagging in decision making process in major agriculture aspects but their participation in all other activities is commendable and higher than that of males. Marketing is the other male-dominated activity, as males feel it is their responsibility when it comes to activities involved with interacting with people outside the home, which again reflects the social confinement of females in the traditional societies. Amrit Patel (2012) Farm produce is marketed commonly by men and that gives them complete control over household finance. 
Amidst the scenario of dominance of males in decision making even after larger contribution of females in agriculture, it becomes extremely important to recognize the role of females in agriculture as a farmer and to empower them to the extent that they equally participate in decision making process. Giving them freedom to take decisions and involving them in the training and conducting of development programs could go a long way in enhancing women's role and their overall contribution in the rural economy. Female participation in agricultural activities is affected by several factors among which their lower level of educational attainment and larger involvement and burden of domestic chores mainly play a major role. To deal with these two major issues, policy initiatives should concentrate towards reducing the domestic work burden of females and increasing their education-skill-awareness level; these steps if rightly implemented, could go a leap ahead in not only developing the state of agriculture in these regions but could also go a long way ahead in empowering the women of these socially backward and economically deprived regions of the state.

\section{REFERENCES}

Amrit Patel. 2012. Empowering women in agriculture. Yojana, pp. 19-22.

Bibhu, S. Behera and Anama C. Behera. 2013. Gender Issues: The Role of Women in Agriculture Sector in India. International Journal of Marketing, Financial Services $\mathcal{E}$ Management Research, 2: 134-145.

Kandari, P. and Bahuguna,U. 2017. Associative analysis of Socio-Economic and Nutritional status of Adult females in the Hill Rural Areas of Uttarakhand: A Study of Pauri, Tehri and Rudraprayag districts. Indian Journal of Development Research and Social Action, 13: 99-112.

Nautiyal, Annapurna. 2013. Women and Development in the Garhwal Himalayas. AJWS. 9: 93-113.

Olsen, Wendy, and Smita Mehta. 2006. A Pluralist Account of Labour Participation in India. Working Paper, Global Poverty Research Group, Manchester: University of Manchester.

Rawat, Rajiv. 2004. Chipko's Quiet Legacy: Forest Rights, Women's Empowerment, Peoples' Institutions, and New Urban Struggles in Uttarakhand, India. York University, Ontario, Canada (mimeo).

Sekhar, C.S.C. 2007. Viable Entrepreneurial Trade for Women in Agriculture in Utttaranchal. Working Report. Agriculture Economics Research Centre, University of Delhi. 
